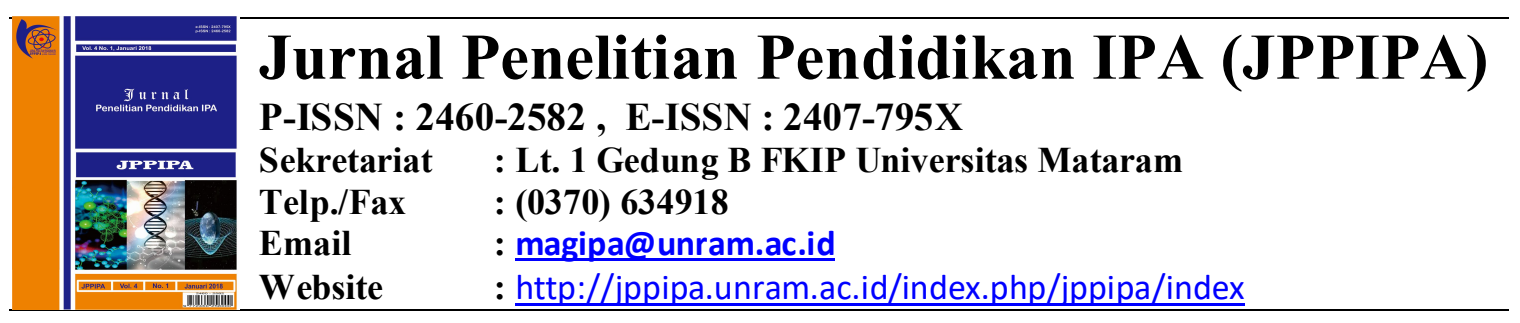

\title{
BAKTERI ENDOFIT KULIT BATANG TANAMAN CENGKEH (Syzygium aromaticum L.) DAN KEMAMPUANNYA SEBAGAI ANTIBAKTERI
}

Citra Sepriana, Dwi Soelistya Dyah Jekti, Lalu Zulkifli

Program Studi Magister Pendidikan IPA Universitas Mataram

Email: citra.sepriana@gmail.com

\begin{tabular}{|c|c|}
\hline Key Words & Abstract \\
\hline $\begin{array}{l}\text { Bark of the } \\
\text { cloves, } \\
\text { Endophytic } \\
\text { bacterial, } \\
\text { Molecular } \\
\text { identification }\end{array}$ & $\begin{array}{l}\text { This research was conducted to find out the capabilities of endophytic bacteria } \\
\text { isolated from bark of the clove plants in inhibiting the growth of bacteria } \\
\text { Streptococcus mutans, Staphylococcus aureus, Klebsiella pneumoniae and } \\
\text { Escherichia coli and to identify endophytic bacteria that potensial to produce } \\
\text { an antibacterial. Stages of this research include the isolation of endophytic } \\
\text { bacteria, antibacterial test, biochemical test, and molecular identification based } \\
\text { on } 16 \mathrm{~S} \text { rRNA. It was obtained about } 29 \text { isolates from bark of the cloves plants } \\
\text { in which } 6 \text { of them isolates inhibited bacterial S. aureus and } 3 \text { isolates inhibited } \\
\text { bacterial S. aureus and S. mutans. Based on } 16 S \text { rRNA molecular identification, } \\
\text { isolates of endophytic bacterial of cloves plants bark which have inhibitory is } \\
\text { closely related to Bacillus cereus JL and Bacillus amyloliquefasiens. }\end{array}$ \\
\hline Kata Kunci & Abstrak \\
\hline $\begin{array}{l}\text { Kulit batang } \\
\text { tanaman } \\
\text { cengkeh, } \\
\text { Bakteri } \\
\text { endofit, } \\
\text { Identifikasi } \\
\text { molekuler }\end{array}$ & $\begin{array}{l}\text { Telah dilakukan penelitian untuk mengetahui kemampuan isolat bakteri endofit } \\
\text { kulit batang tanaman cengkeh untuk menghambat pertumbuhan bakteri } \\
\text { Streptococcus mutans, Staphylococcus aureus, Klebsiella pneumoniae dan } \\
\text { Escherichia coli dan mengidentifikasi jenis bakteri endofit yang memiliki daya } \\
\text { hambat. Tahapan penelitian ini adalah melakukan isolasi bakteri endofit, uji daya } \\
\text { hambat, uji biokimia, dan melakukan identifikasi molekuler } 16 \mathrm{~S} \text { rRNA. Isolasi } \\
\text { bakteri endofit menghasilkan } 29 \text { isolat dari kulit batang tanaman cengkeh, } 6 \\
\text { isolat memiliki daya hambat terhadap bakteri } S \text {. aureus dan } 3 \text { isolat menghambat } \\
\text { bakteri } S \text {. mutans dan } S \text {. aureus. Berdasarkan identifikasi molekuler dengan } 16 \mathrm{~S} \\
\text { rRNA, isolat bakteri endofit kulit batang tanaman cengkeh yang memiliki daya } \\
\text { hambat berkerabat dengan Bacillus amyloliquefasiens dan Bacillus cereus JLh }\end{array}$ \\
\hline
\end{tabular}

PENDAHULUAN

Sejak dahulu manusia telah memanfaatkan bahan alam sebagai bahan obat. Saat ini, meskipun teknologi dan ilmu pengetahuan telah maju serta banyak dihasilkan obat-obatan sintetik, ternyata masyarakat masih menggunakan obat-obat tradisional. Hal ini disebabkan selain karena harganya terjangkau, pengobatan dengan cara tradisional kurang menimbulkan efek samping dibandingkan dengan obat-obatan sintetik (Selviana, 2009).
Salah satu bahan dari alam berupa tanaman obat tradisional yang banyak dimanfaatkan di Indonesia adalah cengkeh (Syzygium aromaticum). Cengkeh sejak lama digunakan dalam industri makanan, minuman, dan obat-obatan tradisional. Tanaman cengkeh memiliki kandungan minyak yang cukup tinggi dan mempunyai sifat khas karena semua bagiannya mulai dari akar, batang, daun, sampai dengan bunganya mengandung minyak atsiri (Kumala dan Indriani, 2008). 
Minyak cengkeh merupakan ekstrak tanaman cengkeh yang memiliki bahan antimikroba alami. Minyak cengkeh mengandung eugenol, caryophyllene, eugenol acetate, dan alpha humelene. Komponen utama dan bahan aktif dalam minyak cengkeh ialah eugenol (Ayoola et al., 2008). Penelitian Andries et al., (2014) menunjukkan bahwa ekstrak cengkeh memiliki efek antibakteri dalam menghambat pertumbuhan bakteri Streptococcus mutan.

Bakteri endofit memiliki kemampuan menghasilkan senyawa aktif. Umumnya senyawa aktif diperoleh dengan mengekstraksi tanaman, khususnya tanaman obat. Untuk memperoleh senyawa aktif dari tanaman dibutuhkan waktu dan proses yang lebih rumit dibandingkan jika mengekstraksi senyawa dari bakteri (Purwanto et al., 2014). Besar kemungkinan bakteri endofit yang menetap pada tanaman tersebut memiliki kemampuan untuk mensintesis senyawa antibakteri yang sama seperti tanaman inangnya (Kusumawati et al., 2014).

Interaksi antara mikroba dengan tanaman inangnya melibatkan transfer materi genetik. Hal ini berdasarkan fakta bahwa zat-zat bioaktif langka yang dihasilkan oleh tanaman tertentu, dihasilkan pula oleh mikroba endofit yang hidup di dalamnya (Strobel, 2002). Pada penelitian ini akan dilakukan isolasi bakteri endofit dari kulit batang tanaman cengkeh, uji daya hambat terhadap bakteri isolat klinik dan identifikasi terhadap bakteri endofit yang mampu menghambat bakteri isolat klinik.

\section{METODOLOGI}

Penelitian ini dilaksanakan pada bulan Maret - November 2016 di Laboratorium Mikrobiologi FKIP Universitas Mataram dan Laboratorium Unit Riset Biomedik RSUD Provinsi Nusa Tenggara Barat. Sampel kulit batang tanaman cengkeh diperoleh di Desa Endut Kecamatan Lingsar Lombok Barat.

\section{Isolasi bakteri endofit}

Sampel kulit batang yang telah dipotong disterilisasi dengan direndam dalam alkohol 70\%, $\mathrm{NaOCl} 4 \%$, dan dibilas dengan aquades. Potongan sampel yang sudah disterilisasi ditanam dalam media TSA, dan diinkubasi pada suhu $32^{\circ} \mathrm{C}$. Isolat bakteri endofit yang tumbuh dimurnikan (Desriani et al., 2014, dengan modifikasi).

\section{Uji daya hambat bakteri endofit}

Isolat bakteri endofit diinokulasi ke dalam medium NB, diinkubasi pada suhu $32^{\circ} \mathrm{C}$ sambil digoyang selama 48 jam, dan disentrifugasi pada $5000 \mathrm{~g}$ selama 30 menit sehingga dihasilkan supernatan. Bakteri uji yang digunakan ada 4 jenis bakteri yaitu Streptococcus mutan, Staphylococcus aureus, Escherichia coli dan Klebsiella pneumoniae. Bakteri uji dibuat pengenceran menggunakan $\mathrm{NaCl}$ $0,9 \%$ dan kekeruhannya distandarisasi dengan CFU $10^{5}$. Uji daya hambat dilakukan dengan metode sumuran pada media MHA, kontrol positif menggunakan ciprofloxacin dan kontrol negatif dengan aquades (Prayoga, 2013, dengan modifikasi).

Uji biokimia

Uji biokimia pada penelitian ini meliputi uji TSI (Triple Sugar Iron), uji Simmon citrat, uji hidrolisis urea, uji motilitas, uji karbohidrat (Glukosa, Sukrosa, Laktosa, Maltosa, Manitol), uji indol, uji katalase, uji hidrolisis pati, uji metal red, dan uji voges proskauer.

\section{Identifikasi molekuler isolat bakteri endofit}

Ekstraksi DNA dilakukan dengan menambahkan 2 ose isolat bakteri endofit dalam $200 \mu 1$ DNAzol, dikocok kuat sebanyak 10 kali, ditambahkan etanol $100 \%$ sebanyak $100 \mu \mathrm{l}$. Larutan bakteri endofit tadi disentrifugasi pada $12.000 \mathrm{~g}$ selama 5 menit. Pelet hasil sentrifugasi ditambahkan etanol 80\% sebanyak $200 \mu 1$ kemudian disentrifugasi pada $9000 \mathrm{~g}$ selama 3 menit (dilakukan 2 kali). Hasil sentrifugasi (pellet) ditambahkan aquades 
$50 \mu 1$ dan disimpan pada $-20^{\circ} \mathrm{C}$ sampai saat digunakan.

Amplifikasi gen 16S rRNA dilakukan menggunakan primer 63f (5'-CAG GCCTAA CACATG CAA GTC-3') dan 1387r (5'-GGG CGG WGT GTA CAAGGC3') (Marchesi et al., 1998). Amplifikasi DNA dilakukan alat PCR My Cycler (Bio Rad). Kondisi awal (pre) PCR diatur pada suhu $94^{\circ} \mathrm{C}$ selama 5 menit, selanjutnya diikuti dengan 35 siklus PCR yang terdiri dari denaturasi pada suhu $94^{\circ} \mathrm{C}$ selama 30 detik, annealing pada suhu $55^{\circ} \mathrm{C}$ selama 30 detik dan extention pada suhu $72^{\circ} \mathrm{C}$ selama 45 detik, setelah 35 siklus terlampaui, dilakukan post PCR pada suhu $72^{\circ} \mathrm{C}$ selama 5 menit dan di simpan pada suhu $20^{\circ} \mathrm{C}$ (Aris et al., 2013, dengan modifikasi).

Elektroforesis dilakukan pada $2 \%$ gel agarose dengan tegangan $100 \mathrm{~V}$ dan kuat arus sebesar 400 A selama 30 menit. Marker yang di pakai adalah 100 bp DNA Ladder (Invitrogen). Hasil elektroforesis difoto menggunakan alat Bio Rad (Aris et al., 2013, dengan modifikasi).

Tabel 1. Hasil pengukuran diameter zona hambat bakteri endofit kulit batang tanaman cengkeh

\begin{tabular}{|c|c|c|c|c|c|}
\hline \multirow[b]{2}{*}{ No } & \multirow{2}{*}{$\begin{array}{c}\text { Isolat } \\
\text { bakteri } \\
\text { endofit }\end{array}$} & \multicolumn{4}{|c|}{ Rata-rata diameter zona hambat (mm) } \\
\hline & & $\begin{array}{c}\text { Streptococcus } \\
\text { mutan }\end{array}$ & $\begin{array}{c}\text { Staphylococcus } \\
\text { aureus }\end{array}$ & $\begin{array}{c}\text { Escherichia } \\
\text { coli }\end{array}$ & $\begin{array}{c}\text { Klebsiella } \\
\text { pneumoniae }\end{array}$ \\
\hline 1 & KC 1 & 13.5 & 17.3 & - & - \\
\hline 2 & $\mathrm{KC} 2$ & - & 12.6 & - & - \\
\hline 3 & $\mathrm{KC} 3$ & 12.6 & 13.6 & - & - \\
\hline 5 & $\mathrm{KC} 6$ & - & 13.8 & - & - \\
\hline 6 & $\mathrm{KC} 7$ & - & 12.6 & - & - \\
\hline 7 & $\mathrm{KC} 8$ & - & 12.6 & - & - \\
\hline 8 & $\mathrm{KC} 9$ & & 15.5 & - & - \\
\hline 9 & $\mathrm{KC} 10$ & 13.6 & 15.8 & - & - \\
\hline
\end{tabular}

Keterangan: $\quad \mathrm{KC}=$ isolat bakteri endofit kulit batang tanaman cengkeh

Kontrol positif $(+)=$ ciprofloxacin

Kontrol negatif $(-)=$ aquades

Daya hambat yang terbentuk menunjukkan adanya pengaruh dari senyawa metabolit sekunder yang dihasilkan oleh bakteri endofit yang berasal dari kulit batang tanaman cengkeh. Hasil diameter daya hambat isolat bakteri endofit menunjukkan bahwa isolat bakteri
Produk PCR selanjutnya disekuensing di 1stBase Malaysia melalui PT Genetika Science Jakarta. Data sekuen DNA yang diperoleh dianalisis menggunakan software Bioedit dan MEGA 6, hasilnya kemudian dibandingkan dengan sekuen yang ada pada GenBank yang terdapat pada situs NCBI (http://www.ncbi.nlm.nih.gov).

\section{HASIL DAN PEMBAHASAN \\ Bakteri endofit hasil isolasi}

Bakteri endofit yang berhasil diisolasi dari kulit batang tanaman cengkeh adalah 29 isolat. Isolat bakteri endofit yang diperoleh kemudian dilakukan uji daya hambat (uji aktivitas antibakteri).

\section{Aktivitas daya hambat bakteri endofit}

Hasil penelitian uji daya hambat isolat bakteri endofit dari kulit batang tanaman cengkeh $(\mathrm{KC})$ menunjukkan bahwa dari 29 isolat bakteri endofit ada 3 isolat $(\mathrm{KC} 1$, KC3 dan KC10) yang memiliki daya hambat terhadap bakteri uji $S$. mutan dan S. aureus, 6 isolat (KC2, $\mathrm{KC} 5, \mathrm{KC} 6, \mathrm{KC} 7$, $\mathrm{KC} 8$, KC9) memiliki daya hambat terhadap bakteri uji $S$. aureus (Tabel 1). endofit kulit batang tanaman cengkeh memiliki potensi antibakteri yang kuat (sensitif). Rata-rata diameter daya hambat menunjukkan bakteri endofit tersebut memiliki potensi antibakteri kuat. Hal ini sesuai dengan pernyataan Susanto et al., (2012), yaitu daya hambat dengan 
diameter $20 \mathrm{~mm}$ ke atas menandakan memiliki potensi antibakteri sangat kuat, daerah hambatan dengan diameter 11-20 $\mathrm{mm}$ memiliki potensi antibakteri kuat (sensitif), daerah hambatan dengan diameter 6-10 $\mathrm{mm}$ memiliki potensi antibakteri sedang (intermediate), dan daerah hambatan dengan diameter kurang dari 5 potensi antibakterinya lemah (resisten).

Hasil penelitian ini menunjukkan bahwa bakteri endofit yang diperoleh hanya dapat menghambat bakteri Gram positif ( $S$. mutan dan $S$. aureus) tetapi tidak dapat menghambat bakteri uji Gram negatif ( $E$. coli dan $K$. pneumoniae). Hal ini menunjukkan bakteri Gram positif lebih rentan terhadap antibakteri. Hal ini sesuai dengan pendapat Pelczar dan Chan (2005), bakteri Gram positif cenderung lebih sensitif terhadap komponen antibakteri. Hal ini disebabkan oleh struktur dinding sel bakteri Gram positif berlapis tunggal yang relatif lebih sederhana sehingga memudahkan senyawa antibakteri untuk masuk ke dalam sel dan menemukan sasaran untuk bekerja. Sedangkan bakteri Gram negatif lebih resisten terhadap senyawa antibakteri karena struktur dinding sel bakteri Gram negatif terdiri dari tiga lapis dan lebih kompleks.

\section{Morfologi bakteri endofit dan karakteristik biokimia}

Hasil pengamatan morfologi dan uji biokimia terlihat pada Tabel 2. Hasil pengecatan Gram menunjukkan semua bakteri endofit termasuk Gram positif, memiliki bentuk sel basil dan bakteri endofit yang diperoleh dapat membentuk spora. Bakteri yang dapat menghasilkan spora lebih tahan terhadap tekanan lingkungan yang ekstrim karena metabolisme selnya terhenti atau dormansi jika berada pada lingkungan yang buruk (Jenson dan Moir, 2003).

Tabel 2. Hasil morfologi dan uji biokimia isolat bakteri endofit kulit batang tanaman cengkeh

\begin{tabular}{|c|c|c|c|c|c|c|c|c|c|c|}
\hline No & $\begin{array}{c}\mathbf{U j i} / \\
\text { Isolat }\end{array}$ & KC1 & $\mathrm{KC2}$ & KC3 & KC5 & КС6 & KC7 & KC8 & KC9 & KC10 \\
\hline 1 & Gram & + & + & + & + & + & + & + & + & + \\
\hline 2 & Bentuk sel & basil & basil & basil & basil & basil & Basil & basil & Basil & basil \\
\hline 3 & Pembentukan spora & + & + & + & + & + & + & + & + & + \\
\hline 4 & $\begin{array}{l}\text { TSI: } \\
\text { Lereng/ dasar } \\
\mathrm{H}_{2} \mathrm{~S} / \mathrm{GaS}\end{array}$ & $\begin{array}{l}a / a \\
-/-\end{array}$ & $\begin{array}{l}a / a \\
-/-\end{array}$ & $\begin{array}{l}a / a \\
-/-\end{array}$ & $\begin{array}{l}\mathrm{b} / \mathrm{a} \\
-/-\end{array}$ & $\begin{array}{l}b / a \\
-/-\end{array}$ & $\begin{array}{l}\mathrm{b} / \mathrm{a} \\
-/-\end{array}$ & $\begin{array}{l}\mathrm{b} / \mathrm{a} \\
-/-\end{array}$ & $\begin{array}{l}\mathrm{b} / \mathrm{a} \\
-/-\end{array}$ & $\begin{array}{l}\mathrm{b} / \mathrm{a} \\
-/-\end{array}$ \\
\hline 5 & Simon citrate & - & - & - & \pm & \pm & \pm & \pm & - & \pm \\
\hline 6 & Urea & - & - & - & - & - & - & - & - & - \\
\hline 7 & Motilitas & + & + & + & + & + & + & + & + & + \\
\hline 8 & Glukosa & + & + & + & - & + & + & + & + & + \\
\hline 9 & Sukrosa & \pm & + & + & + & + & + & + & - & + \\
\hline 10 & Laktosa & - & - & - & - & - & - & - & - & - \\
\hline 11 & Maltosa & - & - & - & - & + & + & + & - & - \\
\hline 12 & Manitol & - & - & \pm & - & - & - & - & - & \pm \\
\hline 13 & Indol & - & - & - & - & - & - & - & - & - \\
\hline 14 & Hidrolisis pati & + & + & + & + & + & + & + & + & + \\
\hline 15 & $\mathrm{Mr} / \mathrm{Vp}$ & $-/-$ & $-/+$ & $-/-$ & $-/-$ & $-/+$ & $-/+$ & $-/-$ & $-/+$ & $-/-$ \\
\hline 16 & Katalase & + & + & + & + & + & + & + & + & + \\
\hline
\end{tabular}

Keterangan: $\mathrm{a}=$ asam, $\mathrm{b}=$ basa, $\mathrm{Mr}=$ metil red, $\mathrm{Vp}=$ voges proskauer. 


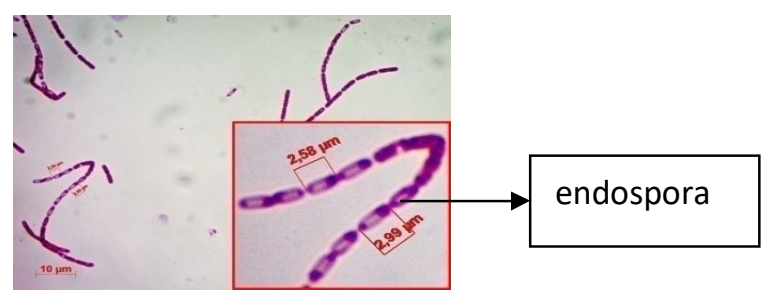

Gambar 1. Sel bakteri Gram positif isolat KC6 bentuk basil

Analisis molekuler isolat bakteri endofit

Hasil penelitian memperlihatkan adanya pita DNA penyandi gen $16 \mathrm{~S}$
rRNA dengan ukuran \pm 1324 bp setelah dibandingkan dengan DNA marker (100 bp DNA ladder) (Gambar 2).

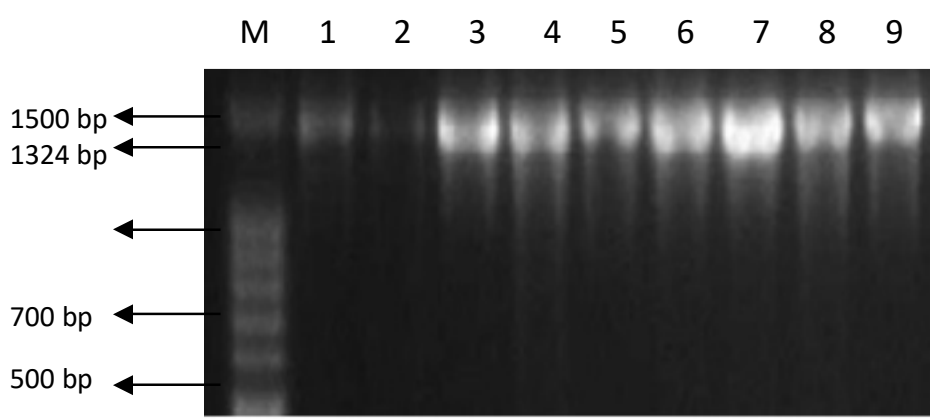

Gambar 2. Hasil elektroforesis dari amplifikasi 16S rRNA isolat bakteri endofit kulit batang (KC) tanaman cengkeh dengan ukuran pita DNA \pm 1324 bp. M (DNA marker), 1 (KC1), 2 (KC2), 3 (KC3), 4 (KC5), 5 (KC6), 6 (KC7), 7 (KC8), 8 (KC9), 9 (KC10).

Hasil sekuensing gen 16S rRNA diolah dengan menggunakan program BioEdit. Data hasil BioEdit tiap isolat dianalisis dengan data di GenBank. Hasil perbandingan sekuensing ini kemudian divisualisasikan dalam bentuk pohon filogenetik dengan menggunakan program MEGA 6 yang dapat menunjukkan kekerabatan isolat sampel dengan sekuen yang diperoleh.

Tabel 3. Jarak genetik (genetic distance) isolat bakteri endofit kulit batang tanaman cengkeh terhadap bakteri referensi yang diakses dari GenBank.

\begin{tabular}{|c|c|c|l|}
\hline No & $\begin{array}{c}\text { Isolat Bakteri } \\
\text { Endofit }\end{array}$ & Jarak Genetika & \multicolumn{1}{|c|}{$\begin{array}{c}\text { Bakteri Referensi/ Kekerabatan Bakteri } \\
\text { Endofit }\end{array}$} \\
\hline 1 & KC1 & 0,006 & Bacillus amyloliquefasies \\
\hline 2 & KC2 & 0,005 & Bacillus amyloliquefasies \\
\hline 3 & KC3 & 0,08 & Bacillus amyloliquefasies \\
\hline 4 & KC5 & 0,005 & Bacillus amyloliquefasies \\
\hline 5 & KC6 & 0,037 & Bacillus careus JL \\
\hline 6 & KC7 & 0,120 & Bacillus amyloliquefasies \\
\hline 7 & KC8 & 0,120 & Bacillus amyloliquefasies \\
\hline 8 & KC9 & 0,120 & Bacillus amyloliquefasies \\
\hline 9 & KC10 & 0,009 & Bacillus amyloliquefasies \\
\hline
\end{tabular}

Data urutan basa gen penyandi $16 \mathrm{~S}$ rRNA memungkinkan digunakan untuk mengkonstruksi pohon filogenetik yang dapat menunjukkan nenek moyang dan hubungan kekerabatan organisme, tetapi organisme yang sekerabat atau identik berdasarkan parameter ini belum tentu memiliki kesamaan secara fisiologi (Ward, 1998). 


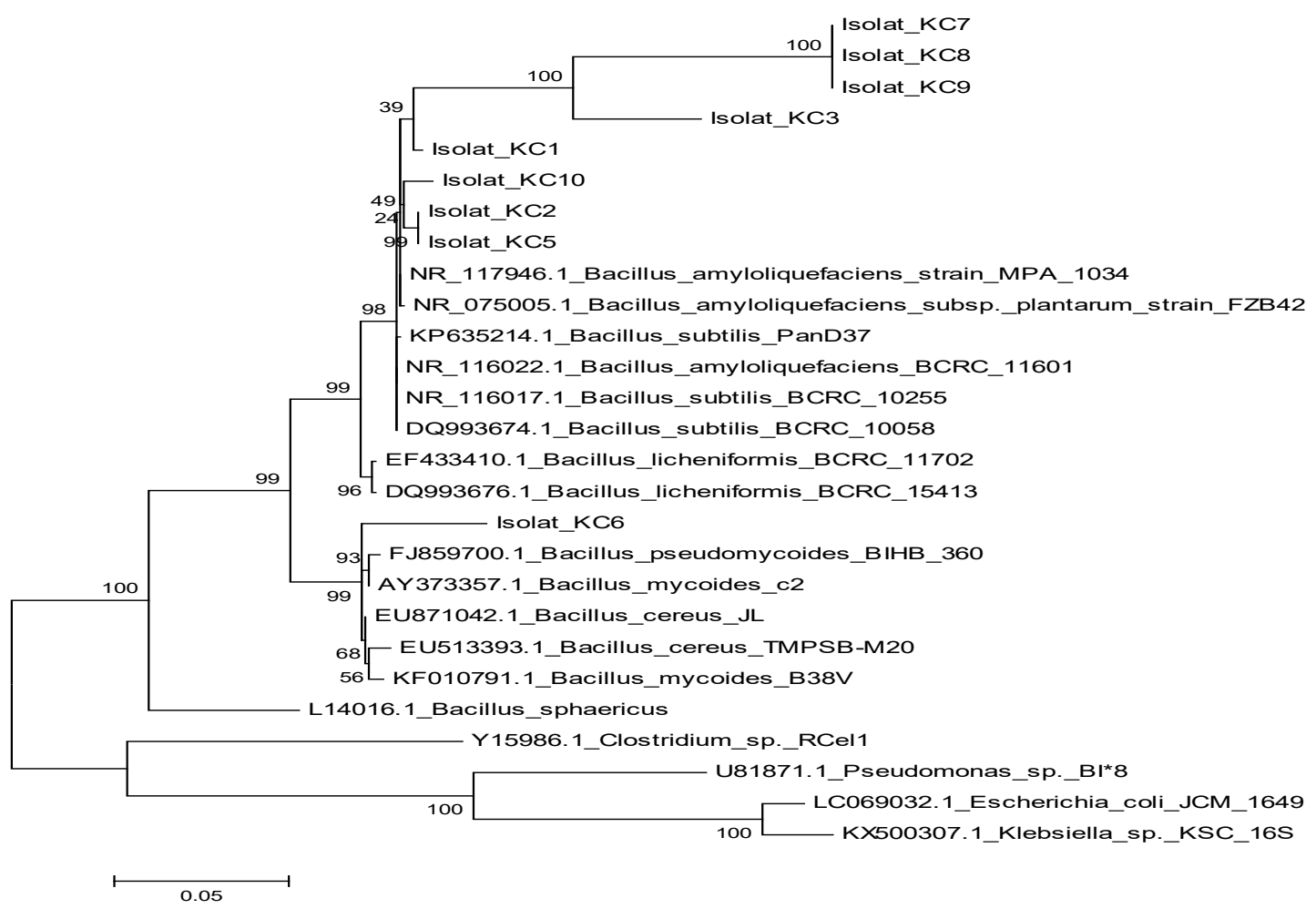

Gambar 3. Pohon filogenetik berdasarkan sekuen gen 16S rRNA dari isolat- isolat bakteri endofit kulit batang tanaman cengkeh.

Berdasarkan jarak genetik dan pohon filogenetik isolat bakteri endofit tanaman cengkeh secara molekuler menunjukkan isolat bakteri endofit yang diperoleh termasuk genus Bacillus. Isolat bakteri endofit dari kulit batang tanaman cengkeh (Tabel 5), memiliki kekerabatan dengan $B$. amyloliquefaciens (isolat $\mathrm{KC} 1, \mathrm{KC} 2$, $\mathrm{KC} 3, \mathrm{KC} 5, \mathrm{KC} 7, \mathrm{KC} 8, \mathrm{KC} 9, \mathrm{KC} 10)$ dan Bacillus cereus $J L$ (isolat KC6).

Hasil penelitian menunjukkan isolat bakteri endofit dari tanaman cengkeh mampunyai kemampuan untuk menghambat bakteri isolat klinik yaitu $S$. mutan dan $S$. aureus. Kemampuannya untuk menghambat karena adanya senyawa metabolit yang dimiliki isolat bakteri endofit. Hal ini sesuai dengan pernyataan Backman dan Sikora (2008), yaitu senyawa yang dikeluarkan mikroba endofit berupa senyawa metabolit sekunder yang merupakan senyawa bioaktif dan dapat berfungsi untuk membunuh patogen. Mikroba endofit memiliki prospek yang baik dalam penemuan sumber-sumber senyawa bioaktif yang dalam perkembangan lebih lanjut dapat dijadikan sebagai sumber penemuan obat untuk berbagai macam penyakit. Menurut Ganiswara (2003), zat antimikroba harus mempunyai sifat toksisitas tinggi tetapi tidak untuk hospes.

Menurut Djatmika (2007), bakteri endofit efektif mengendalikan beberapa patogen karena mempunyai kemampuan hidup pada permukaan dan masuk jaringan daun sesudah jaringan inang, serta mendegradasi komponen dinding sel dengan enzim hidrolitik (selulase, pektinase, dan xilanase).

Penelitian Suryadi et al., (2015) menunjukkan bahwa $B$. cereus $11 \mathrm{UJ}$ menghasilkan 3 senyawa utama, yaitu cyclolanostan, cyclohexyliden, dan stigmast. Metabolit sekunder yang dihasilkan dari ekstrak bakteri $B$. cereus 11UJ dapat menghambat pertumbuhan cendawan $R$. solani dan $P$. oryzae.

$B$. amyloliquefaciens strain FZB42 diketahui mampu mensekresikan senyawa 
lantibiotic mersacidin. Mersacidin ini akan mengikat prekursor lipid II kemudian menghambat biosintesis dinding sel bakteri sehingga bakteri patogen tidak akan bisa bertahan dan beregenerasi (Herzner et al., 2011).

\section{KESIMPULAN}

Isolat bakteri endofit dari kulit batang tanaman cengkeh mempunyai daya hambat terhadap bakteri $S$. mutans dan $S$. aureus sebanyak 3 isolat dan 6 isolat menghambat bakteri $S$. aureus. Isolat bakteri endofit kulit batang tanaman cengkeh memiliki kekerabatan dengan Bacillus amyloliquefaciens dan Bacillus cereus $J L$.

\section{DAFTAR PUSTAKA}

Andries, J.R., Gunawan, P.N., Supit, A. 2014. Uji Efek Bakteri Bunga Cengkeh terhadap Bakteri Streptococcus mutans Secara In Vitro. Jurnal e-GIGI (eG). Vol.2 (2): $1-8$

Aris, M., Sukenda, Harris, E., Sukadi, MF., Yuhana, M. 2013. Identifikasi molekular bakteri patogen dan desain primer PCR. Budidaya Perairan. Vol. 1, No. 3: 43-50.

Ayoola, G.A., Lawore, F.M., Adelowotan, T., Aibinu, I.E., Adenipekun, E., Coker, H.A.B., Odugbemi, T.O,. 2008. Chemical Analysis and Antimicrobial Activity of The Essential Oil Syzigium aromaticum (Clove). Afr. J. Microbiol. Res. Vol.(2) pp. 162166.

Backman PA, dan Sikora RA. 2008. Endophytes: an emerging tool for biological control. Biol Control. 46(1):1-3. doi:10.1016/j.bio control.2008.03.009.

Desriani, Safira UM, Bintang M, Rivai A, Lisdiyanti P. 2014. Isolasi dan
Karakterisasi Bakteri Endofit dari Tanaman Binahong dan Katepeng China. Jurnal Kesehatan Andalas. 2014; 3(2).

Djatmika. 2007. Potensi Dari Tiga Genus Bakteri Dari Tiga Rhizosfer Tanaman Sebagai Agensia Pengendalian Hayati Penyakit Lincat. J. Ilmu-ilmu Pertanian Indonesia, vol.9, (1): 40-47.

Ganiswara, SG. 2003. Farmakologi dan Terapi. Edisi 4. Jakarta: Fakultas Kedokteran Universitas Indonesia.

Herzner, A. M., J. Dischinger, C. Szekat, M. Josten, S. Schmitz, A. Yake'le'ba, R. Reinartz, A. Jansen, H. G. Sahl, J. Piel and G. Bierbaum . 2011. Expression of the Lantibiotic Mersacidin in Bacillus amyloliquefaciens FZB42. Plos one Journal, 6(1): 18

Jenson I, dan Moir CJ (2003) Bacillus cereus and other Bacillus species. Ch 14 In: Hocking AD (ed) Foodborne microorganisms of public health significance. 6th ed, Australian Institute of Food Science and Technology (NSW Branch), Sydney, p. 445-478.

Kumala, S.dan Indriani, D., 2008. Efek Antibakteri Ekstrak Etanol Daun Cengkeh (Eugenia aromaticum L). Jurnal Farmasi Indonesia. Vol.4. (2): 82-87.

Kusumawati DE., Pasaribu FH., Bintang M., 2014. Aktivitas antibakteri isolat bakteri endofit dari tanaman miana (Coleus scutellariodes [L.]Benth.)terhadap

Staphylococcus aureus dan Escherichia coli. Curr. Biochem. 1 (1): 45-50 
Marchesi JR, Sato T, Weightman AJ, Martin TA, Fry JC, Hiom SJ, Wade WG. 1998. Design and evaluation of useful bacteriumspecific PCR primers that amplify genes coding for bacterial $16 \mathrm{~S}$ rRNA. Appl Environ. Microbiol 64:795-9.

Pelczar, MJ., and Chan. 2005. Dasar-Dasar Mikrobiologi 2. Hadieotomo, RS, Imas, T., Tjitrosomo, SS., dan Angka, SL. Penerjemah : UI Press, Jakarta. Terjemahan dari : Elements of Microbiology

Prayoga, E. 2013.Perbandingan Efek Ekstrak Daun Sirih Hijau (Piper betle L) Dengan Metode Difusi Disk Dan Sumuran Terhadap Pertumbuhan Bakteri Staphylococcus aureus.Fakultas Kedokteran dan Ilmu Kesehatan Universitas Islam Negeri Syarif Hidayatullah. Jakarta.

Purwanto, UMS., Pasaribu, FH., dan Bintang, M. 2014. Isolasi Bakteri Endofit dari Tanaman Sirih Hijau (Piper betle L.) dan Potensinya sebagai Penghasil Senyawa Antibakteri. Curr. Biochem. 1 (1): 51-57. e-ISSN: 2355-7877.

Selviana, S., 2009, Uji Daya Antimikroba dari Destilat Caryophylli flos terhadap Strptococcus pyogenes dan Candida albicans. Unika Widya Mandala Surabaya

Strobel, G.A. 2002. Microbial Gifts From Rainforests. Can. J. Plant Phathology.

Suryadi Y, Samudra IM, Priyatno TP, Susilowati, DN, Lestari P, Sutoro. 2015. Aktivitas Anticendawan Bacillus cereus $11 U J$ terhadap. Jurnal Fitopatologi. ISSN: 02157950 Volume 11, Nomor 2.

Susanto, D. Sudrajat dan R. Ruga. 2012. Studi kandungan bahan aktif tumbuhan meranti merah (Shorea leprosula Miq) sebagai sumber senyawa antibakteri. Mulawarmnan ScientifieS 11(2): 181-190

Ward, D.M. 1998. A natural species concepts for procaryotes. Current Opinion in Microbiology 1: 271277.

Zinniel DK, Lambrecht P, Beth Harris N, Feng Z, Kuczmarski D, Higley P, Ishimaru CA, Arunakumari A, Barletta RG, Vidaver AK. 2002. Isolation and characterization of endophytic colonizing bacteria from agronomic crops and prairie plants. Appl Environ Microbiol. 68(5):2198-2208. 